\title{
Sociocultural integration of meskhetian turks in the context of inter-ethnic cooperation
}

\section{СОЦІОКУЛЬТУРНА ІНТЕГРАЦІЯ ТУРКІВ-МЕСХЕТИНЦІВ В КОНТЕКСТІ МІЖЕТНІЧНОГО СПІВРОБІТНИЦТВА}

Received: February 27, 2021

Accepted: March 28, 2021

\author{
Written by: \\ Lyudmila Afanasieva ${ }^{85}$ \\ https://orcid.org/0000-0002-9386-6529 \\ Iryna Bukrieieva ${ }^{86}$ \\ https://orcid.org/0000-0002-7444-8321 \\ Lyudmila Glyns'ka ${ }^{87}$ \\ https://orcid.org/0000-0003-2223-2024 \\ Natalia Hlebova ${ }^{88}$ \\ https://orcid.org/0000-0003-3417-1337 \\ Roman Oleksenko $^{89}$ \\ https://orcid.org/0000-0002-2171-514X
}

\begin{abstract}
The article considers the main stages of formation, the main internal and external factors of development of the Ukrainian community of Meskhetian Turks in the current contexts of socio-political realities of today. Based on the analysis of theoretical sources and applied research of problems, factors, nature and directions of ethnocultural adaptation of Meskhetian Turks in Ukraine, there are the tendencies of growth of social mobility and migration activity, democratization of marital and family relations, diversification of employment, significant changes in social, cultural and educational environment, places of compact residence of Ukrainian Meskhetian Turks. The culturological and sociological study of the problems of sociocultural adaptation and the definition of the content elements and the target direction of the system target regional programs of ethnocultural adaptation of the youth of Meskhetian Turks in Ukraine are actualized. It is justified the need to predict sociocultural trends and timely creation of adequate mechanisms and development the forms and methods of coordination of cultural policy in the field of education in the multicultural environment of the south-eastern regions of Ukraine.
\end{abstract}

\begin{abstract}
Анотація
В статті розглянуті основні етапи становлення, основні внутрішні і зовнішні чинники розвитку української громади турків-месхетинців в актуальних контекстах соціально-політичних реалій сьогодення. На основі аналізу теоретичних джерел і прикладних досліджень проблем, чинників, характеру i спрямувань етнокультурної адаптації турків-месхетинців в Україні засвідчують тенденції зростання соціальної мобільності і міграційної активності, демократизації шлюбно-сімейних відносин, диверсифікації форм зайнятості, значних видозмін в соціальному, культурному та освітньому середовищах місць компактного проживання українських турків-месхетинців. Актуалізується культурологічне і соціологічне вивчення проблем соціокультурної адаптації та визначення змістових елементів і цільового спрямування системних цільових регіональних програм етнокультурної адаптації молоді турків-месхетинців в Україні. Обгрунтовується потреба прогнозування соціокультурних тенденцій і своєчасного створення адекватних механізмів i розробки форм i методів координації культурної політики в сфері освіти у полікультурному середовищі південносхідних регіонів України.
\end{abstract}

\footnotetext{
85 Associate Professor of the Department of Sociology Bohdan Khmelnitsky Melitopol State Pedagogical University, Ukraine.

${ }^{86}$ Associate Professor of the Department of Sociology Bohdan Khmelnitsky Melitopol State Pedagogical University, Ukraine.

${ }^{87}$ Associate Professor of the Department of Sociology Bohdan Khmelnitsky Melitopol State Pedagogical University, Ukraine.

${ }^{88}$ Associate Professor of the Department of Sociology Bohdan Khmelnitsky Melitopol State Pedagogical University, Ukraine.

${ }^{89}$ Dr. Sc. in Philosophy, Professor of the Department of Social and Human Sciences, Dmytro Motornyi Tavria State Agrotechnological University, Melitopol, Ukraine.
} 


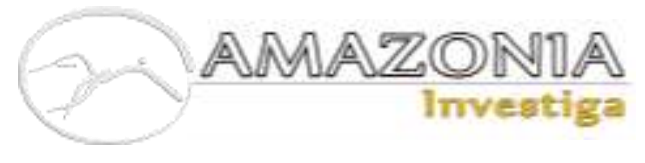

Key Words: Turkish-Meskhetian community of Ukraine, sociocultural adaptation, multicultural territorial community, principle of interculturality, ethnocultural policy.

\section{Introduction}

Analysis of the specifics of historical origins of migration processes and the course of further sociocultural adaptation of many national minorities in Ukraine indicates that migration processes with their peculiarities of close humanitarian contact of different groups of population are accompanied by significant changes both in sociocultural environment of regions that is connected with the formation of certain types of perception the minorities by other social groups and different adaptive consequences for the minorities themselves and is characterized by different levels of motivation for active public life, readiness for sociocultural dialogue. It is especially difficult to adapt when it comes to ethnic, national and religious differences, when there are interpersonal / intrapersonal ethnocultural choices - when ethnic stereotypes and norms of behavior, formed in another sociocultural way of life, are insufficient for full communication, and new norms or stereotypes of interethnic dialogue are in the process of their formation.

The duration of compact living together in different regions of Ukraine of many ethnic groups contributed to their adaptation. However, the multi-ethnicization of many regions of the country caused the problem of regional cultural and historical diversity, which is most evident in features of geopolitical, ethnocultural and religious orientations. Objectively, these trends are largely due to the painful processes of change in the social status of a large part of the population. The object of our study is one of the least studied until recently ethnic group of Meskhetian Turks, where are the certain elements of their isolation, the problem of realization of certain cultural and educational needs, features of family and marriage relations and religious life. European integration policy and involvement of Ukraine in pan-European migration processes in the period of their significant intensification raises the problem of full integration of migrants and establishment of intercultural interethnic interaction between the local population and ethnic groups whose ethnocultural characteristics are quite different and unusual. An important scientific task is the culturological analysis of the features and
Ключові слова: турецько-месхетинська спільнота України, соціокультурна адаптація, багатокультурна територіальна громада, принцип інтеркультурності, етнокультурна політика.

identification of the main factors of the process of sociocultural integration and adaptation of Meskhetian Turks in Ukrainian society.

The concept of interculturalism lies in finding the forms, means and mechanisms to support cultural differences in the process of interaction «within the framework of fundamental democratic values and international human rights treaties». Based on this, ethnocultural adaptation of Meskhetian Turks is considered through the prism of valueemotional attitudes with a view to predicting approaches to the development of mechanisms for the formation of tolerant relations in the multicultural environment of the south-eastern regions of Ukraine, in particular in Zaporozhzhia Azov region (Pryazovia).

The aim of the study is to clarify the role of sociocultural factors that determine the nature of the processes of sociocultural integration of the members of Turkish-Meskhetian communities in polyethnic territorial communities in modern Ukraine.

\section{Literature Review}

An important place in the study of problem of social adaptation of migrants representing the ethnic groups in Ukraine is occupied by the works of Ukrainian scientists: V. Arbenina, O. Blinova, A. Leonova, V. Yevtukh and many others on various issues related to ethnicity, ethnic groups.

Among the researchers who are directly involved in the Turkish-Meskhetian issues, we note the works of Ukrainian scientists: M. Gomaniuk, O.Sirinska and M. Mayorov, O. Malynovska, V. Szczepanskiy, O.Yarosh, Y. Zolotarev who are the authors of a number of scientific works related to the stay of Meskhetian Turks in Ukraine. Much work is dedicated to Meskhetian Turks in other countries. The most famous are the works of E. Aktepe, M. Tekdere, A. Shukhan Hiurbiuz, A. Khachili, A. Poladoglu.

The analysis of scientific sources allows to state that active systematic researches of communities of Turks-Meskhetians as representatives of 
separate ethnic groups in Ukraine (Yevtukh, Troschinsky, Galushko, \& Chernova, 2004) have been going on since the late 1990s (Klynchenko, \& others 1999). In 2006, a thorough ethnosociological essay by O. Malynovska «Meskhetian Turks in Ukraine» was published, which presented a detailed picture of the socioeconomic life of Meskhetian Turks at that time (Malinovskaia, 2006). The Turkish-Meskhetian minority in Ukraine was mainly formed as a result of migration from Uzbekistan, where the Turks were deported in 1944 from southern Georgia (Meskhi) and forced to leave owing to interethnic conflicts in 1989-1990 and seek asylum in the former Soviet Union in Ukraine. The detailed analysis of the peculiarities of the formation and adaptation of the TurkishMeskhetian minority in Ukraine is presented in a comprehensive dissertation study by $\mathrm{M}$. Gomaniuk «Social adaptation and integration of Meskhetian Turks in Ukrainian society» (2007) (Gomaniuk, 2007).

\section{Methodology}

Assessment of the forced migrants' adaptation processes under different civilizational factors of the other cultures influence on the socialization processes in their ethnic environment, in the post-Soviet space is based on the structuralfunctional methodological paradigm, which includes demographic, economic, political, cultural directions taking into account the historical aspects of interethnic interaction.

To analyze trends in the educational level of Meskhetian-Turks, vertical social mobility, migration activity, and the diversification of employment forms of Ukrainian MeskhetianTurks youth, a comparative analysis of the public opinion poll results was used.

Assessing the satisfaction level of cultural and educational needs of female representatives of the Meskhetian Turk communities in the context of various influencing factors (features of the social structure, economic and political behavior of the region, attention to the problems of state authorities, local government and public organizations, media, religious communities, educational institutions in different countries) used the content analysis of articles published in the regional media of the areas where they live in.

The applied part of the study was conducted using such methods as archival document analysis, observation, in-depth interview and semi-structured interview techniques.
For conducting in-depth and semi-structured interviews (fifteen pieces), guides were developed, based on analyzed archival documents, literature sources, and other sociological research.

During the empirical research by in-depth interview method among the settlement inhabitants of the Melitopol region Meskhetian Turks, the topical problems of the Meskhetian regional community, which need authorities' support, in particular the organization of language, legal and cultural training, assistance in solving social and economic issues and promotion of various interaction forms, were highlighted.

The issues that were appropriate in this study related to the current situation, identification and gender hierarchy, the content and form of gender socialization processes of the TurkishMeskhetian people, the content and structure of the Turkish-Meskhetian ethno-cultural stereotype of femininity, Problems of gender inequality in the Turkish-Meskhetian ethnoenvironment related to the traditional lifestyle, the distribution of gender roles and responsibilities in the modern TurkishMeskhetian community were considered in the instrumentalist and constructivist research paradigms of socio-normative cultures.

In the above context, to find out the reasons, motives, mental aspects of the Meskhetian women's behavior in different life cycles of Melitopol district and Melitopol, six wedding ceremonies (video materials were provided by respondents) of Meskhetian Turks were analyzed, which embody the moral and ethical ideals of the nation in creating a new family, view of marriage and the relationship between spouses, reflecting the deep history of the nation, the evolution of the family, the gender program for Meskhetian women, family values and providing a social mechanism for transmitting traditional gender roles and norms of behavior to the next generations.

In order to identify ways and possibilities of migrants' functional integration into Ukrainian society under the impact of living in an alien environment, as well as obstacles and difficulties in this process factors contributing to the destruction of destructive ethnic stereotypes in the ethno-contact environment, secondary analysis of sociological research results (in particular studies by A. Gomoniuk, A. Malinovskaya) was additionally used. Statistical materials were used: the results of the 
population census, regional (Zaporizhzhia, Kherson, Nikolaev and Odessa regions), demographic and socio-economic statistics, analysis of state authorities' documents and literary sources.

\section{Results and Discussion}

The aggression of the Russian Federation in the Donbass and the annexation of the Crimea in 2014 became the starting point for the new trials of the community which in Cyrillic sources is mostly called Meskhetian Turks, and in Turkicspeaking sources - Akhiska Turks. In particular, in December 2015, the Turkish authorities organized the evacuation of two thousand Meskhetian Turks from the war-torn Donbass (Slovyansk, Ukraine) to Istanbul. The works of M. Mayorov, O. Sirinska (Sirinska, \& Mayorov, 2015), D. Zolotarev (Zolotarev, 2020) and were devoted to the situation of Meskhetian Turks after the beginning of the conflict in eastern Ukraine. In the context of studying the problems of Ukrainian-Turkish relations and the activities of Islamic organizations in Ukraine, the nature of the situation of Meskhetian Turks is reflected in a number of works by researchers S. Danilov, V. Szczepanskiy, O. Yarosh (Danilov, 2015); (Szczepanskiy, 2017); (Yarosh, 2014). The problems of Meskhetian Turks in Ukraine and immigrants from Donbass are considered in the work of Turkish researchers E. Aktepe, A. Hiurbiuz, M. Tekdere (Aktepe, Tekdere, \& Abdullah Şuhan Gürbüz 2017). The materials of the International Symposium of Meskhetian Turks, which took place in Erzincan in 2017, were widely covered in Ukraine through social networks (Hüsrev, 2017).

According to available statistics, the total number of Meskhetian Turks in the world from various estimates ranges from 400 to 700 thousand people (Kazakhstan: 180 thousand, Russia: 90 thousand, Azerbaijan: 87 thousand, Turkey: 76 thousand, Uzbekistan: 38 thousand, Kyrgyzstan: 42 thousand, USA: 16 thousand, Ukraine: 8 thousand, Georgia: 1.5 thousand). Meskhetian Turks who survived the pogroms in the Fergana Valley of Uzbekistan in 1989 were forced to relocate to neighboring Central Asian countries, as well as to Russia and Ukraine.

About 40,000 Meskhetian Turks migrated to Turkey after the collapse of the Soviet Union. The special Turkish law in 1992 allowed them to migrate to Turkey, and as of August 2004, more than 32,000 migrants had received residence and work permits from the Turkish government, about half of whom had Turkish citizenship and mostly lived in large cities (Antalya, Bursa and Istanbul). Due to the pressure from the Russian authorities and attacks by the local nationalist population in 2004 at the Krasnodar territory, a large number of Meskhetian Turks took advantage of the International Organization for Migration (IOM) program and were able to relocate to the United States.

According to statistical sources, the Turkish community in Ukraine today consists mainly of Meskhetian Turks and natives of Turkey (as of 2009, there were 5,394 Turkish citizens living in Ukraine (According to the All-Ukrainian community «Vatan», from 8 to 10 thousand Meskhetian Turks live in Ukraine now).

Most Meskhetian Turks arrived in Ukraine in 1989-1990 immediately after ethnic persecution in the Fergana Valley in Uzbekistan, or immigrated later to reunite with their relatives. In 1991, the displaced people were granted Ukrainian citizenship. The main places of residence in Ukraine were the Autonomous Republic of Crimea (969 people) (before annexation), Donetsk region (1791 people), Kherson region (3736 people), Mykolaiv region (758 people), Kharkiv region (392 people), Zaporizhzhia region (357 people) (State Statistics Committee of Ukraine, 2001).

The very name of the Meskhetian Turks is conditional. Some researchers attribute this ethnic group to the Turks living on the TurkishGeorgian border, others to Georgians who came under the rule of the Ottoman Empire and were forced to convert to Islam. This view is widespread in Georgia (Hacıl1, Poladoğlu, 2001). However, the name Meskhetian Turks is used in international documents. Although at different times they were called Meskhetians, Sunnis Georgians, Tatars, Azerbaijanis. In Turkey, they became known as the Akhaltsikh Turks, according to the largest city in the region of the former settlement - Akhaltsikhe. In terms of language and traditions, Meskhetian Turks are close to Anatolian Turks. The vast majority of Meskhetian Turks are Sunnis Muslims.

Today, small groups of Meskhetian Turks live in 11 regions of Ukraine. The vast majority of them live in the steppe southern Ukrainian villages of Kherson, Mykolaiv regions, as well as Azov region (Pryazovia) in Zaporizhzhia region. Today, they are citizens of Ukraine, teaching Ukrainian to children in Ukrainian schools. Although there are almost no people left who 
remember their native places in the Transcaucasus. Even older persons, who have heard eyewitness stories about them, are becoming fewer and fewer. However, the relatives gather to cross several state borders at weddings and other holidays. They have their own all-Ukrainian national-cultural society «Vatan», which means «homeland». Its leader is a member of the Council of Representatives of National Minorities under the President of Ukraine.

The analysis of scientific sources shows that Meskhetian Turks living in Ukraine are characterized by multilevel identification. Perceiving the Turkic version of ethnogenesis, the vast majority of Ukrainian Turks identify themselves primarily as «Turks» and secondly as «Meskhetian Turks (Akhaltsikh Turks)». Although the «repatriation» motive remains the main ethnic marker among most Meskhetian Turks, there has been a recent decline in the number of its bearers (among the youth). It can be assumed that it will be replaced by civic identification, which testifies to the integration of Meskhetian Turks into Ukrainian society.

The spread of the endoethnonym «Turks» among Meskhetian Turks in Ukraine suggests that migratory attitudes among Meskhetian Turks are gradually receding into the background, becoming an element of verbal behavior, a part of ethnic myth. Avoiding the «Meskhetian» toponymic predicate, Ukrainian Turks reorient their own vision of «home / homeland». Since there were no organizations in Ukraine (before the aggression of the Russian Federation in the Donbass and the annexation of Crimea) whose program goal would be to go to Turkey, the researchers suggested that such a reorientation had also an integration character (Sirinska, \& Mayorov, 2015).

According to M. Gomaniuk, the adaptation of Meskhetian Turks in Ukraine is quite successful. This was facilitated by the fact that the Meskhetian Turks did not change their status that they had in Uzbekistan. They remained villagers, did not change their livelihoods, etc., and therefore the adaptation was easier. According to E. Malynovska, since there were no state resettlement programs in Ukraine, it took place on its own initiative. However, the resettlement was determined by employment opportunities and obtaining the public housing. That is why the newcomers settled mainly in the countryside of Kherson, Donetsk, Mykolaiv, Zaporizhzhia regions and the Autonomous Republic of Crimea. That is, they settled in the rich in land resources, but relatively sparsely populated steppe region, where agricultural enterprises have traditionally attracted migrants, providing them with housing. She considers the internal migration to be another important factor in the formation and growth of Turkish communities: people try to move to the places where are more representatives from the same tribe, closer to relatives and acquaintances. Marital migration is an important factor (Sirinska, \& Mayorov, 2015). At the same time, the research shows that Meskhetian Turks community has long experienced significant problems with the education of children and youth, especially women. To a large extent, this was due to communication within Turkish communities exclusively in Turkish, as well as to the distribution of gender roles, the intra-community hierarchy, and its leading role of elders. Therefore, in the first years of living in Ukraine, only a few young people were able to continue their education in secondary and higher education institutions. Many people did not even finish high school. There was no talk of teaching girls at all: they left school after 7-8 years of study. However, as the economic situation in the country improves and living standards rise, more and more families are trying to provide children with a full education, realizing that it is the key to better employment and earnings. Almost all young men graduate from school, many of them continue their education. The attitudes towards education and girls are changing. Although many of them still drop out after the 9th grade, they are increasingly receiving a high school diploma as well as higher education. At the same time, the level of student achievement among Meskhetian Turks, according to teachers, is sufficient, but on average lower than local students have. This reduces their chances of continuing the education and the upward social mobility associated with education. The main reason is in the lack of language skills among children that come to school. They have to spend all their time on mastering it in primary school, which causes these students to lag behind in senior classes and creates additional problems for the school. The teachers have to solve them on their own, as there are no special methods or programs designed for immigrant students. To a greater or lesser extent, the school copes with this task. However, there are educational institutions that follow the path of least resistance, creating classes where the majority are Turkish children and the local population is represented by low-achieving students. This approach consolidates the backwardness of Turkish children in education, does not give them any chance to establish social ties outside their community, and cultivates a 
complex of inferiority which can be selfisolation, and aggression against the country of residence, complications of interethnic relations as a consequence (Sirinska, \& Mayorov, 2015).

The Turkish language is not mastered systematically by the Akhiska Turks in Ukraine - through the Turkish media, cinema and music, and for the most part there are some problems with the literary Turkish language, in particular with the written language (Gomaniuk, 2020). However, according to M. Gomaniuk's research, the majority of Meskhetian Turks are aware that language proficiency, personal acquaintances, knowledge of the culture of the neighboring state and education today are social capital that can serve both respondents and both countries. Therefore, today there are tendencies to change the types of employment of the Akhiska Turks, and to increase the number of people with higher education. In particular, in the 1990s only a few members of communities studied in Ukrainian and Turkish universities. Today the children and grandchildren of many respondents and their relatives' study to become doctors, programmers, agronomists, economists and more.

The patrons of the Turkish state have traditionally provided great support and assistance to the Meskhetian Turks communities in this. For example, in 2005, a mosque named after Suleiman the Magnificent was built and opened in Mariupol at the expense of Turkish businessman Salih Dzhykhan. The International Turkish School was opened in the Ukrainian state (Autonomous Republic of Crimea), where Turkish, English, Crimean Tatar and French were taught and included in the list of the 100 best schools in the country. For the third year since its founding, the school has succeeded in city and national competitions, as well as won a bronze medal at the International Olympiad in Environmental Projects (INEPO) in Turkey. Speaker of Parliament Dzhemil Chychek visited the Meridian International School, founded by Turkish entrepreneurs in the Ukrainian capital in 2013.

Although a significant part of Kherson Akhiska Turks remains living in rural areas, the range of their employment has expanded somewhat in recent years. Among them there are successful businessmen, doctors, lawyers, engineers, industry and service workers. Some of them work in companies with Turkish capital, many of which are in Kherson region and in other regions of Ukraine (for example, companies that build highways), or in companies that have trade relations with Turkey. To a large extent, employment to the Meskhetian Turks was provided by construction companies from Turkey operating in Ukraine. In particular, the Meskhetian Turks mentioned that they worked on the construction of Terminal D of Boryspil International Airport, as well as on the construction of highways, residential buildings, and mobile telephone infrastructure in various regions of Ukraine. Since 2012, the citizens of Ukraine, including Meskhetian Turks, have the opportunity to be enrolled in universities of the Republic of Turkey under the program for the countries of Black Sea region (Zolotarev, 2020). A study of the community of Meskhetian Turks of Mykolaiv region shows that today some young people receive higher education in Turkey. If earlier there were quotas for entrants of Meskhetian Turks from Ukraine, today the system had changed. All entrants, regardless of origin, are competitively selected (Sirinska, \& Mayorov, 2015). Ukrainian Akhiska Turks enter / entered mainly universities in Simferopol, Kherson, Zaporizhzhia, Donetsk. Some of those who studied in Crimean and Donetsk educational institutions were forced to interrupt their studies. However, according to the researcher, higher education among Meskhetian Turks is an application for vertical social mobility, for moving to cities, for modernization in general (Gomaniuk, 2020).

One of the important factors affecting the status of the Meskhetian Turkish issue in the context of the international agenda, as well as influencing the processes within the communities of this people, is the activities of national organizations that exist in almost all Meskhetian Turkish settlements. These public structures are coordinated by the World Association of Akhiska Turks (DATÜB - Dünya Ahıska Türkleri Birliği), which works closely with governmental and non-governmental organizations of the Republic of Turkey, as well as other countries of the diaspora (Zolotarev, 2020).

The researchers note that although 3,000 Meskhetian Turks expressed a desire to return to their ancestral lands after the events in Donbas and Crimea, almost no one speaks of leaving Ukraine as final. Houses and part of families remain here (Silayeva, 2021). A few decades ago, interethnic relations between representatives of ancient ethnic groups and Meskhetian Turks in Ukraine were mediated by socio-psychological mechanisms of stereotyping perception (Blynova, 2011), some of which arose 
due to the lack of information about Turks. Today such factors of full-fledged adaptation as correction of ethnopolitical management in the places of residence of Meskhetian Turks within the aggression of the Russian Federation become significant.

According to the expert assessment of the chairman of the International Society of Meskhetian Turks in Ukraine «Vatan» Marat Rasulov, about $70 \%$ of Meskhetian Turks who previously lived in the region returned to the liberated territories of Donbass (Sirinska, \& Mayorov, 2015). Meskhetian Turks, who had to visit the Russian Federation, are disappointed with the attitude of the Russian authorities towards the settlers. They note that they receive a real help only from their relatives. The community is familiar with the situation in Crimea: the local Russian administration is forcibly relocating refugees from the conflict zone (relocates from the peninsula to the hinterland). The annexation of Crimea by the Russian Federation and attempts to destabilize the situation in the eastern and southern regions of Ukraine have had a negative impact on the situation of local Meskhetian Turks. There are fears of overturning the conflict to the Kherson region: «they will pass through our people» because of the places of compact residence of Meskhetian Turks of Kherson region are located mainly near the administrative border with temporarily occupied territory (Sirinska, \& Mayorov, 2015). The representatives of the community could not give the exact number of Meskhetian Turks who moved to Kherson region from the ATO zone, but confirmed their presence and the fact that they mostly stayed with relatives (Sirinska, Mayorov, 2015). It is characteristic that the community of Meskhetian Turks of Mykolaiv region took care not only of migrants to their area, but also the refugees from the conflict zone. They got to the Russian Federation through the «corridor» made to them by the Russian military and fighters. The refugees were without documents and without possibility of employment, and their relatives were their only source of material assistance (Sirinska, \& Mayorov, 2015).

Thus, based on the results of many studies, we can state that during the first decade of the stay in Ukraine there was a certain rural ghettoization of the Turkish-Meskhetian population, which was locked in its rural ethnocultural ghetto. But recently, the opposite trend has been observed: the educational level of Meskhetian Turks is increasing, vertical social mobility and migration activity of Ukrainian Turks are growing, forms of employment are diversifying, etc. This applies primarily to the Turkish-Meskhetian youth, including women, although the level of satisfaction of cultural and educational needs of Meskhetian Turks is quite low (Gomaniuk, 2007).

The analysis of the gender relations of the Turkish-Meskhetian population showed that their value system is quite stable and family and Islam were and remain the most important for the Meskhetians. Family and country ties are of a great importance. The question of where you are from usually means the village in Georgia which your family comes from. Turks know and remember names, dates of birth, places of residence of their relatives up to the fourth generation. Important family events, such as weddings or funerals play significant role for communication. People not only communicate, exchange information when meeting, but also solve important cases. For example, young people meet at weddings, parents agree, and future married couples are formed.

Gender inequality in the environment is directly related to the traditional way of life, distribution of gender roles and responsibilities, according to which it is a woman who should take care of family comfort.

The theoretical sources also confirm that the process of gender socialization of this people covered several stages, which differed in content and form and were aimed at preparing the girl to perform key female social roles - wife, mother, housewife. The highest social status was occupied by elderly women, who managed to realize fully these roles during their lives. For example, the wedding ceremonies of Meskhetian Turks embody the moral and ethical ideals of the people in creating a new family, the view of marriage, the relationship between spouses, reflects the deep history of the people, the evolution of the family, which allows to assert the presence of gender hierarchy in spouse relations. This hierarchy is manifested in double standards of moral evaluation of the behavior of husband and wife. In terms of quality and structure, the Turkish-Meskhetian ethnocultural stereotype of femininity in the eyes of men is largely correlated with the patriarchal canon. The realities of everyday life also show that socionormative culture does not allow deviations from the hierarchical model of gender relations. Therefore, it is expedient to consider not only social issues, cultural identity, history, but also to identify the state of family relations of Meskhetians at the current stage of their 
development, because family and Islamic traditions were and remain the most important for them.

The empirical basis of this study was the materials of interview with representatives of the Meskhetian ethnic group of Melitopol district and Melitopol - the unique city where representatives of 93 ethnic and national groups have lived harmoniously more than 200 years. The use of this method allowed the authors to obtain more complete (which is not always possible in the questionnaire) information about the causes, motives, mental aspects of the behavior of a Meskhetian woman in different life cycles.

The survey shows that the strength of family and country ties among Meskhetian Turks is perceived as a guarantee of security and safety, ethnic self-preservation. It is not surprising that business relationships are usually built on them as well. According to the Meskhetian respondent Shamurat Shamylevych, the role of a woman in a Turkish-Meskhetian family «...by $99.9 \%$ is due to religion. Everything comes from religion. If religion does not forbid, then the peculiarities of nationality are affected. Initially, there could be one in a thousand divorces in the TurkishMeskhetian community. And only as an exception, for two reasons: the wrong behavior of a woman and a man and the shame of the family, or with the consent of both parties, because of biological factors that make it impossible to continue the family in this couple. And so, the Meskhetian Turks respect and adhere to their traditions that are passed down from generation to generation».

The analysis of documents and in-depth interviews conducted during the empirical study suggest that the content of such a gender program for women was aimed primarily at strengthening the Meskhetian family, family values and providing a social mechanism for the transfer of traditional gender roles and norms of behavior to others generation. The main factor in the development of the gender component of the socialization of Meskhetian Turks into the Ukrainian community remains the patriarchal way of life of the community, religious canons and historical traditions. The specific situation of immigrants and refugees was revealed in the contradictions and uncertainties of the concept of the homeland formed among Meskhetian Turks in Ukraine.
After 30 years of living here, the representatives of this community evaluate their move in general positively. Nazyra states: «It is good that we came here. So many people of Azerbaijan died for nothing in Karabakh, in this war»; «In general, Meskhetian Turks have been living in Krasnodar for 30 years without a residence permit. And there is a big difference in Ukraine. The human rights exist here». However, the gratitude to Ukraine, especially to the elderly persons, looks mostly like a guest's gratitude for a good reception: «I want to thank you and the One who stands above us, that we live here as relatives, that we live as in our own home. Thank you for not insulting us, and for how people welcome us here...» (Iskander).

The arrival of Meskhetian Turks in Ukraine cannot be considered as an act of free choice. They were forced to leave Uzbekistan as refugees, but came to our country due to a certain coincidence. From the very beginning, they considered their stay here as temporary. The attitude to the current place of residence as a stop on the way to wandering is still evident. Much less than the local population, the Meskhetian Turks are engaged in housing construction, adaptation of the homes: «When we, women, ask for something to rebuild or change in housing, but men do not want. There is no need, we have already done, we have already built and left everything ...» (Nazyra). Although the families are growing, dividing, and increasingly the members of the Turkish community are buying, building, or rebuilding housing, the doubts about the appropriate cost remain: «If I go, no one will return the money to me...» (Shamurat).

A sense of temporality is manifested in insecurity and constant vigilance. «First of all, people try to survive, to save themselves, their children. That's why they try to lay low» said Halyna Kuzadzhyeva, a young Turk. This opinion is confirmed by a local resident Nadiia Tovchyhrechko: «And yet they themselves and the children are told not to squeak or say something, to be silent, quietly... The children constantly hear, be silent, say nothing, you are not on your own homeland, you are abroad».

Shamurat Akhmedov, a respondent to our survey, was somewhat more optimistic about the problems with education. Although he acknowledged the specifics of the national approach to education of the girls. He claimed that «There are mostly 80 percent of Meskhetians educated. Women seem to be less educated in 
higher education, however, there are special secondary schools, where they can study».

So, today, based on the experience of more than 30 years of life of Meskhetian Turks in Ukraine, there is every reason to believe that this immigrant minority needs the support of the authorities, in particular, with the organization of language, legal and cultural education, assistance in solving socio-economic issues, assistance to national and cultural public organizations, encouragement of various forms of interaction (Gomaniuk, 2007).

As we can conclude from the results of many studies, the situation of Meskhetian Turks in Ukraine allows us to predict that most of the current citizens of Ukraine of TurkishMeskhetian ethnicity will remain in Ukraine forever, and will be one of the elements of diverse ethnic composition of its population. The conclusions of the latest studies of the ethnic group of the Turkish-Meskhetian population in Ukraine over the past decades are showing the trends in social mobility and migration activity, democratization of marital and family relations, diversification of employment, significant changes in Ukrainian social, cultural and educational environments of Ukrainian Turks in the context of pan-European ethno-integrative processes. These statements also actualize the problem of studying the factors of full-fledged adaptation of Turkish-Meskhetian youth in the Ukrainian community. This approach is especially important in our study, because today the Meskhetian Turks are the people dispersed among other ethnic groups, which causes significant influences of other cultures on socialization processes in their ethnic environment. These processes intensify in an era of globalization, when neighboring ethnic groups change rapidly under the influence of various civilization factors (Gomaniuk, 2007).

Although in economic and socio-political life the social adaptation of Meskhetian Turks tends to integrate (Gomaniuk, 2007), there are traditional for Muslim culture elements of isolation (marital and family relations, religious life) and avoidance of any assimilation in the gender aspect of relations within the Meskhetian community (Arbienina, 2007). Historical, economic, political, demographic, religious, as well as environmental and technogenic factors can act as factors in changing the behavior of an ethnic group. Such problems include the activities of the state and its migration policy, the activities of public resettlement organizations, employment opportunities, issues related to residence permit and registration, the role of the media, and so on. The problems directly related to cultural and socio-cultural adaptation are no less important, but poorly covered in the literature: difficulties arising from a number of differences of ethnocultural nature, professional self-realization, psychological discomfort, lack of communication, etc. These problems can be leveled by systemic target regional programs of ethnocultural adaptation of youth of certain ethnic groups.

In these conditions, the influence of cultural exchange factors on the transformation of intercultural relations of the inhabitants of the southern region of Ukraine becomes important. For example, today the motivation for migration (condition for «entry») for the forced migrants are a shortage of labor resources in another area, the lack of interethnic tensions as a threat of impossibility of contact in intercultural relations, rejection of prejudice and choice of assimilation behavior as a strategy for immersion in cultural space at the places of new residence. Therefore, the culturological and sociological study of forms and methods of coordination of intercultural aspects of cultural policy for the implementation of targeted actions of certain structures responsible for its implementation in a set of coordinated activities is relevant. Such actions will help to lay the foundation for the future conscious ethnocultural mutual understanding of today's youth of different ethnic groups for many years. The most rational use of the potential of immigrants is in the interests of further development of the Ukrainian state. This is necessary both for the full existence of the ethnic group and its harmonious interaction with the host society. The objective process of formation of immigrant ethnic minorities in Ukraine requires attention not only from special or local authorities and law and order, but also from society as a whole. The society should be prepared for the acceptance and perception of representatives of ethnic groups not typical for Ukraine (Leonova, 2005). That is why European integration policy and Ukraine's involvement in European migration processes in the period of their significant intensification raises the problem of full integration of migrants and intercultural interethnic interaction between the local population and ethnic groups whose ethnocultural characteristics are quite different and unusual. And this demonstrates the appropriateness of applying the concept of interculturalism, which is to find forms, means and mechanisms to support cultural differences in the process of interaction «within the framework of fundamental democratic values 
and international human rights treaties» (Serkan, (S), 2014).

\section{Conclusions}

Ukraine's involvement in global migration processes in the period of their significant intensification creates preconditions for the further formation of new «immigration» minorities, and thus raises the problem of integration of migrants and interethnic interaction between local people and immigrants, whose ethnocultural characteristics are quite different and unusual.

An example of such interaction is the residence of Meskhetian Turks in Ukraine. The analysis of their economic activity, sources of income, level of well-being, access to education, etc. allows to identify the ways and opportunities for functional integration of migrants into Ukrainian society, as well as obstacles and difficulties in this process. The study of social ties within the Turkish community and relations with the local population provides an opportunity to consider the transformation of the ethnic identity of migrants under the influence of living in a nonnational environment, as well as the process of interaction of very different cultures.

One of the most effective measures would be to open the specialized cultural and adaptive training courses for migrant ethnic groups in regional educational institutions of different levels. The external factors of adaptation include tolerance from the entourage in the new environment, active promotion of destructive ethnic stereotypes. The last ones contribute to the formation of the image of the ethnic «we», influence ethnic likes and dislikes, determining future behavior in the ethno-contact environment.

Only such approach in the long run will ensure the education of tolerance, openness, positive attitude to ethnic and cultural diversity not as a threat to an established way of life, but as an opportunity to enrich and diversify it. Only in this way, the emigrants of the last wave, including Meskhetian Turks, will be able to become full citizens of Ukrainian society without losing their ethnocultural identity, enriching and multiplying the traditions of good neighborly relations between different ethnic cultures of Zaporizhzhia Azov region (Pryazovia).

One of the stages of implementation of such a program can be adaptation in the learning process. The school is able to provide nonconformist adaptation strategies, eliminate the initial discomfort of forced stay in a new social environment, allow conscious and systematic development of its traditions, new values and behaviors, which is important for selfdevelopment and personal growth.

Such steps, as well as the introduction of compulsory study of the latest (often tragic) pages of the history of a certain people in the curricula of regional pedagogical educational institutions, will not only attract the attention of the host, but also prevent self-isolation and exclusion from Ukrainian social processes of ethnoculturally conscious youth of national minorities, which does not meet the interests of the minority or Ukrainian society.

\section{Bibliographic references}

Aktepe, E., Tekdere, M., \& Shukhan, A. (2017). An Evaluation on Meskhetian Turks Placed in Erzincan in the Context of Social Cohesion and Integration. Journal of Migration Studies. Vol 3(2).

Arbienina, V. (2007). Ethnosociology. Kh.: V. N. Karazin Kharkiv National University.

Blynova, O. (2011). Factors in determining the adaptation strategies of Ukrainian labor migrants in the country of employment. Problems of political psychology and its role in the formation of the Ukrainian state citizen: Collection of Sciences. Papers. Institute of Social and Political Psychology. Moscow. Millennium. Issued 11.

Danilov, S. (2015). Muslim Communities of Ukraine under the Occupation of Crimea and Certain Regions of Donetsk and Luhansk Regions. Strategies of Transformation and Prevention of Border Conflicts in Ukraine. Lviv: Galicia Publishing Union.

Danilov, S. (2020). Muslim Communities of Kherson in the Context of Regional SocioPolitical Dynamics and Security Challenges. Eastern World, No. 4 Recovered from URL: https://oriental-

world.org.ua/sites/default/files/Archive/2020/4/ 6.pdfc

Gomaniuk, M. (2007). Social adaptation and integration of Meskhetian Turks in Ukrainian society. (Extended abstract of candidate's thesis). Kharkov University, Kharkov.

Gomaniuk, M. (2020). Modernization of the social life of Akhiska Turks in Ukraine. Skhidnyi svit, 2. Recovered from URL: https://www.researchgate.net/publication/34265 2864_The_Modernization_of_Social_Life_of_ Meskhetian_Turks_in_Ukraine 
Hacılı, A. \& Poladoğlu, A. (2001). Meskhetian Turkish folklore. Ankara: Ataturk Cultural Center Publications.

Hüsrev, A. (2017). Ahiska Turks Symposium. Erzincan: Erzincan University. Recovered from URL: $\quad$ https://ebyu.edu.tr/wpcontent/uploads/2017/03/ah\% $\quad$ C4\% $\quad$ B1ska sempozyumu-cilt-1.pdf. Accessed January 20, 2021.

Khachili, A., Poladoglu, A. (2001). Ahiska Turkish folklore. Ankara: Publications of the Ataturk Cultural Center.

Klynchenko, T., Malinovskaya, O., Mingazutdinov, I., \& Shamshur, O. (1999). The situation of Meskhetian Turkish refugees in Ukraine. Office of the United Nations High Commissioner for Refugees in Ukraine, Institute Of International Relations Taras Shevchenko National University of Kyiv, Kyiv: Kompaniia VAITE.

Leonova, A. (2005). State ethno-cultural policy in modern Ukraine: Theory and practice: Monograph. K.: DAKK KIM.

Malinovskaya, E. (2006). Meskhetian Turks in Ukraine: Ethno-Sociological Sketch. Kyiv. Genesis

Serkan, K. (S) (2014). Enskild motion. A national intercultural strategy. Recovered from URL: https://data.riksdagen.se/fil/F4B418D4C2AA-48FE-B8F6-0E0178D4E6BD.

Silayeva, G. (2021). Meskhetian Turks: The Long Journey from Donbass to Turkey. BBC News. Recovered from URL: https://www.bbc.com/ukrainian/society/2015/12 /151225_turkey_from_conflict_zone_dt
Sirinska, A., \& Mayorov, M. (2015). The community of Meskhetian Turks in the conditions of the armed conflict in the east of Ukraine. Eastern World. № 1. Recovered from URL: https://orientalworld.org.ua/sites/default/files/Archive/2015/1/ 15.pdf

State Statistics Committee of Ukraine (2001). Ethnic composition of Ukraine. Available from: http://2001.ukrcensus.gov.ua/eng/. Accessed January 20, 2021.

Szczepanskiy, V. (2017). Turkish factor of humanitarian policy in the east of Ukraine in the period of 2014-2016. Politikus. No. 1. Recovered from URL: http://www.politicus.od.ua/3_2017/3_2017.pdf. Ukrainer (2019). Meskhetian Turks of Ukraine. Who are they? Available from: https://ukrainer.net/turky-ukrajiny/ Accessed January 20, 2021

Yarosh, A. (2014). Theoretical Foundations of the Study of Contemporary Muslim Movements and Organizations in the Context of Globalization. Multiversum. Philosophical Almanac. 10 (138).

Yevtukh, V., Troschinsky, V., Galushko, K., \& Chernova, E. (2004). Ethno-national structure of Ukrainian society. Kyiv. Naukova Dumka.

Zolotarev, D. (2020). On the emigration of Meskhetian Turks from Ukraine to Turkey in 2015-2017. Eastern World. No. 2. Recovered from URL: https://orientalworld.org.ua/uk/Archive/ 2020/2/7 